\title{
Quantification of the Carbon Content of the Fractions of Humic Substances and Total Organic Carbon in Different Production Systems
}

\author{
Carlos Augusto Rocha de Moraes Rego ${ }^{1}$, Jonas Francisco Egewarth ${ }^{1}$, Marcio André Francziskowski ${ }^{1}$, \\ Filipe Eliazar Cremonez ${ }^{1}$, Paulo Sérgio Rabello de Oliveira ${ }^{1}$, Maria do Carmo Lana ${ }^{1}$, Bruna Penha Costa ${ }^{1}$, \\ Eloisa Mattei ${ }^{1}$, Marinez Carpiski Sampaio ${ }^{1}$, Vanessa Aline Egewarth ${ }^{1} \&$ Juan López de Herrera ${ }^{2}$ \\ ${ }^{1}$ West State University of Paraná (UNIOESTE), Marechal Candido Rondon, Brazil \\ ${ }^{2}$ Technical University of Madrid (UPM), Madrid, Spain \\ Correspondence: Carlos Augusto Rocha de Moraes Rego, West State University of Paraná (UNIOESTE), \\ Marechal Candido Rondon, Brazil. Tel: 55-98-98747-1864. E-mail: cassielcarlos@hotmail.com
}

Received: September 27, 2017

Accepted: October 28, 2017

Online Published: November 15, 2017

doi:10.5539/jas.v9n12p152

URL: https://doi.org/10.5539/jas.v9n12p152

\begin{abstract}
Soil organic matter is degraded and easily altered by the type of management. The objective of this work is to determine the total organic carbon and humic substance fractions in the organic matter of the soil with different management types and depths in the western region of Paraná, Brazil. The work was carried out in the Experimental Farm "Professor Antônio Carlos dos Santos Pessoa", belonging to the State University of the West of Paraná. Five soil management systems were evaluated: one area with corn cultivation for silage (CS); other area with succession of crops, with soybean in summer and corn in winter (SC); the next area also with succession of crops, with soy in the summer and oat in the winter (SO); the following area with permanent pasture with Tifton (PP); and the last area with crop-livestock integration (ILC). For each management system, four plots were randomly selected, in each plot three simple samples were collected in a diagonal direction to form a composite sample for the depth of 0.00-0.05 m, 0.05-0.10 m and 0.10-0.15 m. Total organic carbon, fractionation of the humic substances and the AH/AF and EA/HUM ratios were calculated. For most of the analyzed variables, it was verified that there were significant differences $(\mathrm{P}<0.05)$ between the systems evaluated in the studied depths. In the evaluated areas, the PP, SO and ILC systems presented the highest carbon content for all attributes analyzed.
\end{abstract}

Keywords: recalcitrant fraction, soil management organic matter

\section{Introduction}

The search for alternatives to increase crop productivity in recent years has prompted the agricultural sector to seek alternatives to produce more sustainably and thus preserve soil, water and environmental resources (Loss et al., 2009). The soil being a natural resource in constant transformation, the agricultural activity can promote processes of degradation and loss of physical, chemical and biological quality, when adequate management and conservation practices are not considered (Chaer \& Tótola, 2009).

Some systems have been developed in response to this issue, with the common objective of providing a more sustainable management of the soil, as in the case of the no-tillage system (SPD), which advocates the constant maintenance of mulch on the soil, among other objectives; and integrated systems, such as crop-livestock integration (ILC), which combines annual crops and pasture in the same area (Andrioli et al., 2008).

Among the advantages of using these management systems, in relation to the soil factor, we can mention the better soil protection against weathering, especially erosion; maintenance of soil moisture, improvement of soil structural and nutritional characteristics and increase the microbiological activity of the soil (Andrade et al., 2009; Loss et al., 2011). These improvements are related to the contribution of organic matter, which is an attribute that indicates the quality of the soil, directly affecting the structural part and the chemical dynamics of the essential elements (Carneiro et al., 2009).

The organic matter of the soil has in its composition living and non-living beings, the living fraction corresponding to the roots of plants and soil organisms, constituting approximately $4 \%$ of the total. The non-living components of organic matter are represented by decomposing plant residues, humid and 
non-humidified substances. In general, the soil organic matter content can vary from 0.5 to $5 \%$ in the mineral horizons in most of the soils (Primo et al., 2011).

The soil organic matter is altered by the type of management, but also the crop species and environmental factors, such as temperature, light and humidity. Organic matter in turn is present in the soil in the form of unmethylated acidic compounds and humified macromolecules (humic substances). The humic substances correspond to 85 to $90 \%$ of the soil organic matter and are responsible for most of the cation-exchange capacity (CEC) of the soil of organic origin, being the main reasons that make the organic matter fraction of soil the main focus in studies and researches (Barreto, 2008).

It is clear, therefore, that the systems that recommend the maintenance of straw and the use of fodder tend to promote increase of the total soil organic carbon, as well as the proportion of humic substances that improve the quality of the soil. Based on this, the objective of this work is to determine the total organic carbon and humic substance fractions of the soil organic matter with different soil management types and in different depths in the western region of Paraná, Brazil.

\section{Material and Methods}

Soil samples were collected in commercially operated fields with different soil management systems, in place different lengths of time, and conducted on rural properties in the municipality of Marechal Candido Rondon, Western Paraná, Brazil. The climate of the region, according to the classification of Köppen, is Cfa type, subtropical humid, subtropical of dry winter, with rains well distributed throughout the year and hot summers, average annual temperature between 22 to $23^{\circ} \mathrm{C}$ and total precipitation of 1600 to 1800 millimeters (Caviglione et al., 2000). Due to proximity of all areas, the soil is classified as eutrophic Red Latosol (Santos et al., 2013) and in the granulometric analysis we obtained $52.52 \mathrm{~g} \mathrm{~kg}^{-1}$ of sand, $266.48 \mathrm{~g} \mathrm{~kg}^{-1}$ of silt and $681.00 \mathrm{~g} \mathrm{~kg}^{-1}$ of clay for the layer of 0.00 to $0.10 \mathrm{~m}$ and $49.39 \mathrm{~g} \mathrm{~kg}^{-1}$ of sand, $199.11 \mathrm{~g} \mathrm{~kg}^{-1}$ of silt and $751.50 \mathrm{~g} \mathrm{~kg}^{-1}$ of clay for the layer of 0.10 to $0.20 \mathrm{~m}$.

Five areas were evaluated, using a completely randomized design, with four replications. These areas were: an area with productive management of first and second corn crop for silage (CS); an area with succession of crops with soybean in the summer and corn in the winter in no-tillage system for ten years (SC); an area with succession of crops, with soybean in the summer and oat in the winter, in a system of direct sowing (SO), where the oats are desiccated to form cover, this system implemented for five years; an area with permanent pasture with Tifton 85 for harvesting (PP) for ten years; and an area with soybean in the summer and oat in the winter, and grazing animals on oats, five years of establishment (ILC).

Regarding the management of agricultural crops in this area, recommendations were made for fertilization and cultural treatments, due to the specific need for each crop. In relation to the oat cultivation with direct grazing for the ILC system, it started when the plants' height was between 0.25 and $0.35 \mathrm{~m}$ and the animals were removed when their height was $0.15 \mathrm{~m}$, so that there was no damage to the apical meristem, and it would grow again for the formation of straw sufficient for direct planting of soybeans in succession (Fontaneli et al., 2012).

For each management area, four sites were randomly selected; within this area, a composite sample was collected in the diagonal direction, formed by the collection of three sub-samples at depths of $0.00-0.05 \mathrm{~m}$; 0.05-0.10 m and 0.10-0.20 m, subsequently homogenized. The collected samples were air dried, heat dried, macerated and passed through a $2 \mathrm{~mm}$ mesh sieve (TFSA), to perform the following analysis: total organic carbon (TOC), determined by hot oxidation with potassium dichromate (Yeomans \& Bremner, 1988); and chemical fractionation of the humic substances, carried out following the technique of differential solubility, separating the fulvic acids (AF), the humic acids (AH) and the humins (HUM) as established by the International Society of Humic Substances and adapted by Benites et al. (2003).

After separation of the humic substances, the respective total organic carbon contents were determined by hot oxidation with potassium dichromate (Yeomans \& Bremner, 1988), after determination of the contents of each fraction, the following ratios were calculated: AH/AF (indicates soil carbon mobility) and alkaline extract (EA)/HUM (indicates organic matter illuviation in the soil profile), the alkaline extract is the sum of humic acids and fulvic acids.

The degrees of freedom for treatment were decomposed into four orthogonal contrasts within each depth. We worked with average contrasts, dividing the result of each contrast by the respective coefficient (Table 1). The significance of the contrasts was tested by the $\mathrm{F}$ test $(\mathrm{P}<0.05)$, using the statistical software SISVAR (Ferreira, 2014), from the mean square of the combined residue, and the effect of a given characteristic increased or decreased when signs of the estimated contrasts were positive or negative, respectively. 
Table 1. Comparisons of interest, contrasts and coefficients established between treatments

\begin{tabular}{lllllll}
\hline \multirow{2}{*}{ Comparisons of Interest } & \multirow{2}{*}{ Contrasts } & \multicolumn{5}{c}{ Treatments $^{(1)}$} \\
\cline { 4 - 7 } & & PP & CS & SO & ILC & SC \\
\hline Grazing by Agricultural crops & $\mathrm{C} 1$ & 4 & -1 & -1 & -1 & -1 \\
Grain crop by Silage crop & $\mathrm{C} 2$ & 0 & 3 & -1 & -1 & -1 \\
Integrated System by System non-Integration & $\mathrm{C} 3$ & 0 & 0 & -1 & 2 & -1 \\
Succession of oats-soybean by corn-soybean succession & $\mathrm{C} 4$ & 0 & 0 & 1 & 0 & -1 \\
\hline
\end{tabular}

Note. ${ }^{(1)}$ PP: permanent pasture; CS: corn for silage; SO: succession of soybeans and oats; ILC: crop-livestock integration; SC: succession of soybean and corn.

The contrast $\mathrm{C} 1$ establishes a comparison between treatments of permanent pasture and agricultural crops; contrast $\mathrm{C} 2$ compares the treatments of the crop for grain and for silage; contrast $\mathrm{C} 3$ compares the areas that had management with integration of agriculture with grazing on the winter crop, within the same area and an area non-integration; and finally contrast $\mathrm{C} 4$ was established to compare the treatments that had succession of oats in winter with soybean in summer and succession of corn in winter with soybean in summer.

\section{Results and Discussion}

Table 2 presents the results of total organic carbon, carbon fractions of humic substances, relationships of interest and results of mean contrasts for each treatment and depth studied. 
Table 2. Total organic carbon (TOC), fulvic acid (AF), humic acid (AH), humina (HUM), humic acid and fulvic acid ratio (AH/AF), alkaline extract and humina ratio (EA/HUM) and estimates of mean contrasts established for each management system and depth

\begin{tabular}{|c|c|c|c|c|c|c|}
\hline \multirow{2}{*}{ Treatments } & TOC & $\mathrm{AF}$ & $\mathrm{AH}$ & HUM & $\mathrm{AH} / \mathrm{AF}$ & EA/HUM \\
\hline & \multicolumn{6}{|c|}{ - } \\
\hline \multicolumn{7}{|c|}{ Depth of 0.00-0.05 m } \\
\hline PP & 24.46 & 2.96 & 3.00 & 16.62 & 1.02 & 0.37 \\
\hline $\mathrm{CS}$ & 14.77 & 2.72 & 2.16 & 11.16 & 0.80 & 0.44 \\
\hline SO & 24.37 & 2.78 & 3.10 & 14.16 & 1.13 & 0.42 \\
\hline $\mathrm{SC}$ & 19.81 & 2.59 & 2.41 & 14.59 & 0.95 & 0.35 \\
\hline ILC & 20.05 & 2.73 & 3.14 & 14.06 & 1.15 & 0.42 \\
\hline \multicolumn{7}{|l|}{ Contrasts } \\
\hline $\mathrm{C} 1$ & $4.71 *$ & $0.26^{\mathrm{ns}}$ & $0.30^{\mathrm{ns}}$ & $3.12 *$ & $0.01^{\mathrm{ns}}$ & $-0.04^{\mathrm{ns}}$ \\
\hline $\mathrm{C} 2$ & $-6.65 * *$ & $0.03^{\mathrm{ns}}$ & $-0.72 * *$ & $-3.12 *$ & $-0.27 * *$ & $0.05^{\mathrm{ns}}$ \\
\hline $\mathrm{C} 3$ & $-2.04^{\mathrm{ns}}$ & $0.04^{\mathrm{ns}}$ & $0.38^{\mathrm{ns}}$ & $-0.31^{\mathrm{ns}}$ & $0.12^{\mathrm{ns}}$ & $0.04^{\mathrm{ns}}$ \\
\hline $\mathrm{C} 4$ & $4.56^{\mathrm{ns}}$ & $0.18^{\mathrm{ns}}$ & $0.68 * *$ & $-0.42^{\text {ns }}$ & $0.18^{\mathrm{ns}}$ & $0.07^{\mathrm{ns}}$ \\
\hline $\mathrm{CV}(\%)$ & 16.0 & 13.8 & 11.6 & 13.5 & 13.0 & 14.2 \\
\hline \multicolumn{7}{|c|}{ Depth of 0.05-0.10 m } \\
\hline PP & 20.63 & 2.72 & 2.65 & 13.07 & 0.99 & 0.41 \\
\hline $\mathrm{CS}$ & 17.16 & 2.50 & 1.79 & 11.23 & 0.71 & 0.38 \\
\hline $\mathrm{SO}$ & 18.11 & 2.60 & 3.07 & 13.44 & 1.18 & 0.42 \\
\hline $\mathrm{SC}$ & 18.15 & 2.35 & 2.31 & 13.96 & 1.05 & 0.34 \\
\hline ILC & 18.37 & 2.80 & 2.86 & 13.10 & 1.02 & 0.44 \\
\hline \multicolumn{7}{|l|}{ Contrasts } \\
\hline $\mathrm{C} 1$ & $2.68^{\mathrm{ns}}$ & $0.16^{\mathrm{ns}}$ & $0.14^{\mathrm{ns}}$ & $0.14^{\mathrm{ns}}$ & $0.00^{\mathrm{ns}}$ & $0.02^{\mathrm{ns}}$ \\
\hline $\mathrm{C} 2$ & $-1.05^{\mathrm{ns}}$ & $-0.08^{\mathrm{ns}}$ & $-0.95^{* *}$ & $-2.28^{*}$ & $-0.37 * *$ & $-0.02^{\mathrm{ns}}$ \\
\hline $\mathrm{C} 3$ & $0.24^{\mathrm{ns}}$ & $0.32^{\mathrm{ns}}$ & $0.17^{\mathrm{ns}}$ & $-0.60^{\mathrm{ns}}$ & $-0.09^{\mathrm{ns}}$ & $0.05^{\mathrm{ns}}$ \\
\hline $\mathrm{C} 4$ & $-0.03^{\mathrm{ns}}$ & $0.24^{\mathrm{ns}}$ & $0.76^{* *}$ & $-0.52^{\text {ns }}$ & $0.14^{\mathrm{ns}}$ & $0.08^{\mathrm{ns}}$ \\
\hline $\mathrm{CV}(\%)$ & 14.0 & 15.9 & 12.9 & 12.0 & 19.5 & 15.3 \\
\hline \multicolumn{7}{|c|}{ Depth of $0.10-0.20 \mathrm{~m}$} \\
\hline PP & 17.14 & 2.63 & 2.61 & 11.97 & 1.01 & 0.44 \\
\hline $\mathrm{CS}$ & 12.69 & 2.32 & 1.93 & 9.730 & 0.83 & 0.44 \\
\hline $\mathrm{SO}$ & 17.55 & 2.29 & 2.91 & 13.38 & 1.27 & 0.39 \\
\hline $\mathrm{SC}$ & 17.59 & 2.12 & 1.81 & 12.44 & 0.87 & 0.32 \\
\hline ILC & 15.75 & 2.26 & 2.68 & 13.38 & 1.20 & 0.37 \\
\hline \multicolumn{7}{|l|}{ Contrasts } \\
\hline $\mathrm{C} 1$ & $1.25^{\mathrm{ns}}$ & $0.38^{\mathrm{ns}}$ & $0.28^{\mathrm{ns}}$ & $-0.26^{\mathrm{ns}}$ & $-0.03^{\mathrm{ns}}$ & $0.06^{\mathrm{ns}}$ \\
\hline $\mathrm{C} 2$ & $-4.27 *$ & $0.10^{\mathrm{ns}}$ & $-0.54 *$ & $-3.34 * *$ & $-0.28 *$ & $0.08^{\mathrm{ns}}$ \\
\hline $\mathrm{C} 3$ & $-1.82^{\mathrm{ns}}$ & $0.06^{\mathrm{ns}}$ & $0.32^{\mathrm{ns}}$ & $0.47^{\mathrm{ns}}$ & $0.13^{\mathrm{ns}}$ & $0.02^{\mathrm{ns}}$ \\
\hline $\mathrm{C} 4$ & $-0.04^{\mathrm{ns}}$ & $0.17^{\mathrm{ns}}$ & $1.10 * *$ & $0.94^{\mathrm{ns}}$ & $0.40^{* *}$ & $0.08^{\mathrm{ns}}$ \\
\hline $\mathrm{CV}(\%)$ & 20.0 & 14.5 & 17.5 & 12.1 & 18.4 & 16.8 \\
\hline
\end{tabular}

Note. The row data represent the analysis for each contrast established in the analyzed variables. CV: coefficient of variation. ${ }^{* *}$ significant at $1 \%$ by the $\mathrm{F}$ test. * significant at $5 \%$ by the $\mathrm{F}$ test. ns: not significant by the $\mathrm{F}$ test, according to the established contrasts.

Regarding the results of the comparisons made for TOC in the depth of $0.00-0.05 \mathrm{~m}$, there was a difference $(\mathrm{P}<$ 0.05 ) in the $\mathrm{C} 1$ contrast, and the average pasture area was $4.71 \mathrm{~g} \mathrm{~kg}^{-1}$ of carbon in the soil more than the other areas. In the comparison performed by the $\mathrm{C} 2$ contrast, there was statistical difference $(\mathrm{P}<0.01)$, in which the grain cultivation areas averaged $6.65 \mathrm{~g} \mathrm{~kg}^{-1}$ of carbon more than the area of corn cultivation for silage. For the comparisons made by the $\mathrm{C} 3$ and $\mathrm{C} 4$ contrasts there was no difference $(\mathrm{P}>0.05)$ between the comparisons made (Table 2). 
The comparisons made for TOC in the depth of 0.05-0.10 m, did not present statistical difference $(\mathrm{P}>0.05)$. For the depth of $0.10-0.20 \mathrm{~m}$ there was a statistical difference $(\mathrm{P}<0.05)$ only in the comparison carried out by the $\mathrm{C} 2$ contrast, with the average grain yield of $4.27 \mathrm{~g} \mathrm{~kg}^{-1}$ of carbon higher than in the maize cultivation area for silage (Table 2).

The TOC content depends essentially on the input of material on the soil surface and on the process of decomposition or mineralization of the soil organic matter (Martins et al., 2015). The high TOC values present in the pasture are not only related to the amount of material produced, but also to the fact that their material components, such as lignins and polyphenols, are more resistant to degradation, which can guarantee a longer permanence of TOC in a system, when comparing with other (Dortzbach et al., 2015). On the other hand, the low TOC content in the corn area for silage is explained by the removal of all the aerial biomass produced in the crop area, so that the only input of organic matter comes from the roots and therefore in this system it was lower in all depths (Wendling et al., 2005).

For systems in which the soil is turned over, the organic matter of the soil is distributed throughout the arable layer, which means that the TOC contents in larger depths can be similar or even higher (Ussiri \& Lal, 2009). Carneiro et al. (2009), found similar results so that TOC of planted pastures was higher than several other management systems such as natural pasture and ILC.

Regarding the results of the comparisons made for AF, in all comparisons and depths there was no statistical difference $(\mathrm{P}>0.05)$. As this matter is easily degraded by the edaphic microorganism and also because the soil has been turned over and has incorporated the vegetal remains, a practice that normally increases the levels of $\mathrm{AF}$ in relation to $\mathrm{AH}$ (Loss et al., 2010), the levels were equal between the areas and in the comparisons made.

For all the depths and in the contrasts $\mathrm{C} 2$ and $\mathrm{C} 4$ the $\mathrm{AH}$ had a significant difference, having a mean of $0.72 \mathrm{~g}$ $\mathrm{kg}^{-1}$ and $0.68 \mathrm{~g} \mathrm{~kg}^{-1}$, for the depth of $0.00-0.05 \mathrm{~m}, 0.95 \mathrm{~g} \mathrm{~kg}^{-1}$ and $0.76 \mathrm{~g} \mathrm{~kg}^{-1}$, for the depth of $0.05-0.10 \mathrm{~m}, 0.54$ $\mathrm{g} \mathrm{kg}^{-1}$ and $1.10 \mathrm{~g} \mathrm{~kg}^{-1}$, to the depth of $0.10-0.20 \mathrm{~m}$, respectively, for each comparison. The results obtained in $\mathrm{C} 2$ show that on average the areas of grain cultivation are higher in relation to the area of maize for silage and for $\mathrm{C} 4$ they show that on average the crop with succession of oats-soybean is higher than the succession corn-soybean.

According to Loss et al. (2010), the non-disturbance of the soil by tillage, and the accumulation of organic matter due to the no-tillage system and the use of forages, allows an increase of $\mathrm{AH}$ in relation to AF. This explains the fact that the areas of grain crops had AH values above the area of maize for silage, since the accumulation of organic matter is higher in these systems.

The fractions AF and AH are less stable because they contain lower molecular mass, so can be easily mineralized, translocated to subsurface or polymerized depths, reducing their soil content (Valladares et al., 2011). The highest values of $\mathrm{AH}$ in comparison to $\mathrm{AF}$ are a consequence of the intense humification and the rapid mineralization of the organic material deposited in the soil (Cunha et al., 2007).

In relation to the levels of HUM in the depth of $0.00-0.05 \mathrm{~m}$ in the $\mathrm{C} 1$ contrast, there was a difference between the comparison performed, with the permanent pasture area being, average, $3.12 \mathrm{~g} \mathrm{~kg}^{-1}$ of carbon higher than the other areas; in contrast $\mathrm{C} 2$, there was a difference in all depths, with the grain yield being, $3.12 \mathrm{~g} \mathrm{~kg}^{-1}$ of carbon average more than the cultivation for silage at a depth of $0.00-0.05 \mathrm{~m} ; 2.28 \mathrm{~g} \mathrm{~kg}^{-1}$ carbon, at a depth of $0.05-0.10$ $\mathrm{m}$, and $3.34 \mathrm{~g} \mathrm{~kg}^{-1}$ carbon at a depth of 0.10-0.15 m. The rest of the comparisons made at different depths did not show significant differences.

There is predominance of the humina fraction in comparison with the fractions of humic and fulvic acids, independently of the management system used and the depth analyzed. Humina is the fraction of the carbon that is most closely associated with the mineral colloids of the soil, being randomly distributed in the profiles (Canellas et al., 2000). According to Grinhut et al. (2007), this predominance of the HUM fraction is related to its insolubility and resistance to biodegradation, favored by the formation of stable clay-humic complexes. The predominant mineral composition of soils in studies, composed of $\mathrm{Fe}$ and $\mathrm{Al}$ oxides and hydroxides, favors organo-mineral interactions, increases the protection of the functional groups of easy decomposition of the HUM fraction and contributes to increase their carbon stock (Dick et al., 2003; Dick et al., 2008).

The results found for the $\mathrm{AH} / \mathrm{AF}$ ratio in all depths, both in the $\mathrm{C} 1$ and $\mathrm{C} 3$ contrasts, did not show differences $(\mathrm{P}>0.05)$. In contrast $\mathrm{C} 4$ there was a significant difference only in the depth of $0.10-0.20 \mathrm{~m}$, having the oatssoybean succession system on average a ratio 0.40 higher than the soybean-corn succession system. For the $\mathrm{C} 2$ contrast, there was difference in all the depths, with the area of grain cultivation averaging a ratio of $0.27,0.37$ 
and 0.28 , at depth $0.00-0.05 \mathrm{~m}, 0.05-0.10 \mathrm{~m}$ and $0.10-0.15 \mathrm{~m}$, respectively, higher than for silage. This difference has the same relation as explained by Loss et al. (2010) for AH and AF, previously discussed.

The AH/AF ratio is an indicator of humus quality, since it expresses the degree of evolution of the organic matter humification process, where values lower than 1.0 indicate selective loss of AF or less synthesis and accumulation of the most stable fraction (AH) (Fontana et al., 2005; Bonifácio et al., 2006), which is common in tropical soils, indicating low rates of humification and mineralization of organic matter, being a reflection of low base content, soil acidity and restriction of microbial activity (Miranda et al., 2007). The relationships higher than 1.0 are explained by soil and climate conditions, where the polymerization and condensation processes are favorable (Valladares et al., 2007).

For comparisons for the EA/HUM ratio at all depths there was no difference $(\mathrm{P}>0.05)$. The low values of the EA/HUM ratio indicate the high stability between the organic matter and the mineral matrix of these soils, provided by the interaction between 2:1 clays and the $\mathrm{Ca}$ and $\mathrm{Mg}$ ions with the ionized $\mathrm{COOH}$ and $\mathrm{OH}$ functional groups, mainly of organic matter (Canellas et al., 2008).

\section{Conclusion}

The permanent pasture area had higher levels of TOC and HUM than the other systems evaluated, mainly in the 0.00-0.05 $\mathrm{m}$ depth.

Grain cultivation areas had higher TOC, AH, HUM and AH/AF levels than the maize cultivation area for silage in all depths evaluated.

The comparison between integrated system and non-integration system for all variables and depths analyzed did not show differences.

The soybean-soybean succession area had only higher AH contents than the corn-soy succession area.

\section{Acknowledgements}

We want to give thanks to the Coordination for the Improvement of Higher Education Personnel (CAPES) by the scholarship of the master's degree and resources for conducting the research. To the technician of the Laboratory of Fertility and Plant Nutrition of the State University of the West of Paraná, as well as the coordination of the postgraduate course in agronomy of the State University of Western Paraná and the National Council for Scientific and to Technological Development $(\mathrm{CNPq})$ for the productivity scholarship granted to the researcher Dr. Paulo Sérgio Rabello Oliveira.

\section{References}

Andrade, R. da S., Stone, L. F., \& Silveira, P. M. da. (2009). Culturas de cobertura e qualidade física de um Latossolo em plantio direto. Revista Brasileira de Engenharia Agrícola e Ambiental, 13(4), 411-418. https://doi.org/10.1590/S1415-43662009000400007

Andrioli, I., Beutler, A. N., Centurion, J. F., Andrioli, F. F., \& Coutinho, E. L. M. (2008). Produção de milho em plantio direto com adubação nitrogenada e cobertura do solo na pré-safra. Revista Brasileira de Ciência do Solo, 32(4), 1691-1698. https://doi.org/10.1590/S0100-06832008000400034

Balbinot Junior, A. A., Moraes, A. de V., Milton, P. A., \& Dieckow, J. (2009). Integração lavoura-pecuária: intensificação de uso de áreas agrícolas. Ciência Rural, 39(6), 1925-1933. https://doi.org/10.1590/ S0103-84782009005000107

Barreto, A. C., Freire, M. B. G. dos S., Nacif, P. G. S., Araújo, Q. R., Freire, F. J., \& Inácio, E. dos S. B. (2008). Fracionamento químico e físico do carbono orgânico total em um solo de mata submetido a diferentes usos. Revista Brasileira de Ciência do Solo, 32(4), 1471-1478. https://doi.org/10.1590/S0100-06832008000 400011

Bonifacio, E., Santoni, S., Celi, L., \& Zanini, E. (2006). Spodosol - Histosol evolution in the Krkonos e National Park (CZ). Geoderma, 131, 237-250. https://doi.org/10.1016/j.geoderma.2005.03.023

Campos, L. P., Leite, L. F. C., Maciel, G. A., Brasil, E. L., \& Iwata, B. de F. (2013). Estoques e frações de carbono orgânico em Latossolo Amarelo submetido a diferentes sistemas de manejo. Pesquisa Agropecuária Brasileira, 48(3), 304-312. https://doi.org/10.1590/S0100-204X2013000300009

Canellas, L. P., Berner, P. G., Silva, S. G. da, Silva, M. B., \& Santos, G. de A. (2000). Frações da matéria orgânica em seis solos de uma toposseqüência no Estado do Rio de Janeiro. Pesquisa Agropecuária Brasileira, 35(1), 133-143. https://doi.org/10.1590/S0100-204X2000000100016 
Canellas, L. P., Santos, G. A., \& Amaral Sobrinho, N. M. B. (2008). Reações da matéria orgânica. In G. A. Santos, et al. (Eds.). Fundamentos da matéria orgânica do solo: Ecossistemas tropicais \& subtropicais (2nd ed., pp. 45-64). Porto Alegre, Metrópole.

Carneiro, M. A. C., Souza, E. D. de, Reis, E. F. dos, Pereira, H. S., \& Azevedo, W. R. de. (2009). Atributos físicos, químicos e biológicos de solo de cerrado sob diferentes sistemas de uso e manejo. Revista Brasileira de Ciência do Solo, 33(1), 147-157. https://doi.org/10.1590/S0100-06832009000100016

Chaer, G. M., \& Tótola, M. R. (2007). Impacto do manejo de resíduos orgânicos durante a reforma de plantios de eucalipto sobre indicadores de qualidade do solo. Revista Brasileira de Ciência do Solo, 31(6), 1381-1396. https://doi.org/10.1590/S0100-06832007000600016

Cunha, T. J. F., Madari, B. E., Benites, V. de M., Canellas, L. P., Novotny, E. H., Moutta, R. de O., ... Santos, G. de A. (2007). Fracionamento químico da matéria orgânica e características de ácidos húmicos de solos com horizonte a antrópico da amazônia (Terra Preta). Acta Amazonica, 37(1), 91-98. https://doi.org/10.1590/ S0044-59672007000100010

Dick, D. P., Santos, J. H. Z., \& Ferranti, E. M. (2003). Chemical characterization and infrared spectroscopy of soil organic matter from two southern brazilian soils. Revista Brasileira de Ciência do Solo, 27(1), 29-39. https://doi.org/10.1590/S0100-06832003000100004

Dick, D. P., Silva, L. B. da, Inda, A. V., \& Knicker, H. (2008). Estudo comparativo da matéria orgânica de diferentes classes de solos de altitude do sul do Brasil por técnicas convencionais e espectroscópicas. Revista Brasileira de Ciência do Solo, 32(6), 2289-2296. https://doi.org/10.1590/S0100-068320080006 00008

Dortzbach, D., Pereira, M. G., Blainski, É., \& González, A. P. (2015). Estoque de C e Abundância Natural de 13C em Razão da Conversão de Áreas de Floresta e Pastagem em Bioma Mata Atlântica. Revista Brasileira de Ciência do Solo, 39(6), 1643-1660. https://doi.org/10.1590/01000683rbcs20140531

Ferreira, D. F. (2014). Sisvar: A guide for its Bootstrap procedures in multiple comparisons. Ciência e Agrotecnologia, 38(2), 109-112. https://doi.org/10.1590/S1413-70542014000200001

Fontana, A., Anjos, L. H. C., Sallés, J. M., Pereira, M. G., \& Rossiello, O. R. P. (2005). Carbono orgânico e fracionamento químico da matéria orgânica em solos da Sierra de Ánimas-Uruguai. Floresta e Ambiente, 12 , 36-43.

Fontaneli, R. S., Santos, H. P., \& Fontaneli, R. S. (2012). Forrageiras para Integração Lavoura-Pecuária-Floresta na Região Sul-Brasileira (2nd ed., p. 544). Brasília, DF: Embrapa Trigo.

Grinhut, T., Hadar, Y., \& Chen, Y. (2007). Degradation and transformation of humic substances by saprotrophic fungi: Processes and mechanisms. Fungal Biology Reviews, 21, 179-189. https://oi.org/10.1016/ j.fbr.2007.09.003

Loss, A., Pereira, M. G., Giácomo, S. G., Perin, A., \& Anjos, L. H. C. (2011). Agregação, carbono e nitrogênio em agregados do solo sob plantio direto com integração lavoura-pecuária. Pesquisa Agropecuária Brasileira, 46(10), 1269-1276. https://doi.org/10.1590/S0100-204X2011001000022

Loss, A., Pereira, M. G., Schultz, N., Anjos, L. A. H. C. dos, \& Silva, E. M. R. da. (2009). Carbono e frações granulométricas da matéria orgânica do solo sob sistemas de produção orgânica. Ciência Rural, 39(4), 1067-1072. https://doi.org/10.1590/S0103-84782009005000036

Loss, A., Pereira, M. G., Schultz, N., Anjos, L. H. C. dos, \& Silva, E. M. R. da. (2010). Quantificação do carbono das substâncias húmicas em diferentes sistemas de uso do solo e épocas de avaliação. Bragantia, 69(4), 913-922. https://doi.org/10.1590/S0006-87052010000400018

Martins, C. M., Costa, L. M. da, Schaefer, C. E. G. R., Soares, E. M. B., \& Santos, S. R. dos. (2015). Frações da Matéria Orgânica em Solos Sob Formações Deciduais no Norte de Minas Gerais. Revista Caatinga, 28(4), 10-20. https://doi.org/10.1590/1983-21252015v28n402rc

Miranda, C. do C., Canellas, L. P., \& Trindade Nascimento, M. (2007). Caracterização da matéria orgânica do solo em fragmentos de mata atlântica e em plantios abandonados de eucalipto. Revista Brasileira de Ciência do Solo, 31(5), 905-916. https://doi.org/10.1590/S0100-06832007000500008

Primo, D. C., Menezes, R. S. C., \& Silva, T. O. (2011). Substâncias húmicas da matéria orgânica do solo: uma revisão de técnicas analíticas e estudos no nordeste brasileiro. Scientia Plena, 7(5), 1-13. 
Santos, H. G. dos, Jacomine, P. K. T., Anjos, L. H. C. dos, Oliveira, V. Á. de, Lumbreras, J. F., Coelho, M. R., ... Oliveira, J. B. de. (2013). Sistema brasileiro de classificação de solos (3rd ed., p. 353). Brasília: Empresa Brasileira de Pesquisa Agropecuária (EMBRAPA).

Ussiri, D. A. N., \& Lal, R. (2009). Long-term tillage effects on soil carbon storage and carbon dioxide emissions in continuous corn cropping system from an Alfisol in Ohio. Soil and Tillage Research, 104, 39-47. https://doi.org/10.1016/j.still.2008.11.008

Valladares, G. S., Batistella, M., \& Pereira, M. G. (2011). Alterações ocorridas pelo manejo em Latossolo, Rondônia, Amazônia Brasileira. Bragantia, 70(3), 63-637. https://doi.org/10.1590/S0006-870520110003 00019

Valladares, G. S., Pereira, M. G., Anjos, L. H. C., Benites, V. M., Ebeling, A. G., \& Mouta, R. O. (2007). Humic substance fractions and attributes of histosols and related high-organic-matter soils from brazil. Communications in Soil Science and Plant Analysis, 38, 763-777. https://doi.org/10.1080/0010362070 1220759

Wendling, B., Jucksch, I., Mendonça, E. de S., \& Neves, J. C. L. (2005). Carbono orgânico e estabilidade de agregados de um Latossolo Vermelho sob diferentes manejos. Pesquisa Agropecuária Brasileira, 40(5), 487-494. https://doi.org/10.1590/S0100-204X2005000500010

Yeomans, J. C., \& Bremner, J. M. (1988). A rapid and precise method for routine determination of organic carbon in soil. Communications in Soil Science and Plant Analysis, 19, 1467-1476. https://doi.org/10.1080/ 00103628809368027

\section{Copyrights}

Copyright for this article is retained by the author(s), with first publication rights granted to the journal.

This is an open-access article distributed under the terms and conditions of the Creative Commons Attribution license (http://creativecommons.org/licenses/by/4.0/). 